\title{
Occurrence of nitrate in Tanzanian groundwater aquifers: A review
}

\author{
Eliapenda Elisante $\cdot$ Alfred N. N. Muzuka
}

Received: 7 October 2014/Accepted: 5 February 2015/Published online: 6 March 2015

(C) The Author(s) 2015. This article is published with open access at Springerlink.com

\begin{abstract}
More than $25 \%$ of Tanzanian depends on groundwater as the main source of water for drinking, irrigation and industrial activities. The current trend of land use may lead to groundwater contamination and thus increasing risks associated with the usage of contaminated water. Nitrate is one of the contaminants resulting largely from anthropogenic activities that may find its way to the aquifers and thus threatening the quality of groundwater. Elevated levels of nitrate in groundwater may lead to human health and environmental problems. The current trend of land use in Tanzania associated with high population growth, poor sanitation facilities and fertilizer usage may lead to nitrate contamination of groundwater. This paper therefore aimed at providing an overview of to what extent human activities have altered the concentration of nitrate in groundwater aquifers in Tanzania. The concentration of nitrate in Tanzanian groundwater is variable with highest values observable in Dar es Salaam (up to $477.6 \mathrm{mg} / \mathrm{l}$ ), Dodoma (up to $441.1 \mathrm{mg} / \mathrm{l}$ ), Tanga (above $100 \mathrm{mg} / \mathrm{l})$ and Manyara $(180 \mathrm{mg} / \mathrm{l})$. Such high values can be attributed to various human activities including onsite sanitation in urban centres and agricultural activities in rural areas. Furthermore, there are some signs of increasing concentration of nitrate in groundwater with time in some areas in response to increased human activities. However,
\end{abstract}

\section{E. Elisante · A. N. N. Muzuka}

Department of Water and Environmental Sciences and

Engineering, Nelson Mandela African Institution of Science and

Technology (NM-AIST), P. O. Box 447, Arusha, Tanzania

\section{E. Elisante $(\square)$}

Department of Physical Sciences, Faculty of Science, Sokoine University of Agriculture (SUA), P.O Box 3038, Morogoro, Tanzania

e-mail: elisante@suanet.ac.tz; marikie@nm-aist.ac.tz reports on levels and trends of nitrate in groundwater in many regions of the country are lacking. For Tanzania to appropriately address the issue of groundwater contamination, a deliberate move to determine nitrate concentration in groundwater is required, as well as protection of recharge basins and improvement of onsite sanitation systems.

Keywords Groundwater contamination · Human activities $\cdot$ Nitrate concentration $\cdot$ Tanzania

\section{Introduction}

\section{Background}

Groundwater makes up to over $95 \%$ of the world's available freshwater resources and is the main source of drinking water for a large percentage of the world's population (Bowell et al. 1996; Brindha and Elango 2011). Groundwater can be found in most environments. Its quantity, quality, accessibility and recharge depend primarily on geology, geomorphology, land use and levels of precipitation. Geology and geomorphology play a significant role on storage, transportation and quality of the groundwater, whereas precipitation plays a significant role on the groundwater recharge (Taylor et al. 2012). Depending on geomorphology and geology of a place, a recharge of $10-50 \mathrm{~mm}$ can occur in the area with annual precipitation of less than $500 \mathrm{~mm}$ (MacDonald and Calow 2009).

Groundwater is an important source of water supplying more than $25 \%$ of the domestic water consumption in Tanzania (Gössling 2001; JICA 2002). Groundwater offers the affordable source of water because it can be found close 
to the point of demand (MacDonald and Calow 2009; Taylor et al. 2012). It is the main source of water for most rural areas of Tanzania and urban areas of Dodoma, Arusha, Manyara, Simiyu, Singida, Shinyanga and Dar es Salaam regions (Bowell et al. 1996, 1997; Kashaigili 2012) and islands of Unguja, Pemba and Mafia (Gössling 2001; Hansson 2010). Utilisation of groundwater resources in Tanzania has grown fast particularly since 1997 when there was a severe surface water crisis (Mato 2002; Mtoni et al. 2012, 2013). For example, more than 10,000 groundwater supply sources have been developed in Dar es Salaam alone since 1997 (Mjemah et al. 2012; Mtoni et al. 2013). However, the quality of groundwater in different aquifers in the country remains poorly understood. Therefore, this calls for a deliberate move to determine the trends and occurrence of various contaminants in the groundwater in order to be able to establish the best groundwater management strategies.

The usefulness of groundwater resources, however, is being compromised by contamination due to natural and human activities (Nkotagu 1996a, b; Tredoux et al. 2000; Reynolds-Vargas et al. 2006). Groundwater quality degradation has been widely reported from both urban and rural areas in developed and developing countries. It is often the cause of an increasing freshwater scarcity, increasing water supply costs and a growing human health hazard (Foster et al. 1999). The sources of groundwater contamination can be categorised into natural or anthropogenic sources (Jiang et al. 2009). Natural sources of contamination include contamination due to water-soil interaction during percolation where water dissolves and/or elute some soluble material from rocks/soil (Carol et al. 2012; Ghiglieri et al. 2012; Rajesh et al. 2012). For example, in Tanzania more than $30 \%$ of all water sources have fluoride concentrations greater than $1.50 \mathrm{mg} / \mathrm{l}$ the maximum allowable concentration in drinking water recommended by WHO (Kaseva 2006). Additionally, human activities may exacerbate groundwater contamination by escalating the rate of slow occurring natural processes. For example, mining activities facilitate acid rock drainage which may result into groundwater with low $\mathrm{pH}$ and high levels of trace elements (Baird 1995).

Potential anthropogenic source of groundwater contamination is domestic sewage especially onsite sanitation systems like pit latrines, cesspits and soak away pits (Nkotagu 1996a; Tredoux et al. 2000; Reynolds-Vargas et al. 2006; Kiptum and Ndambuki 2012). Other sources include industrial effluents, leachate from solid waste dumpsites, leakage from fuel filling stations, automobile and repair garages, industrial workshops and agriculture (Eckhardt and Stackelberg 1995; Goulding 2000; Jalali 2005; Srinivasamoorthy et al. 2009). Contaminants resulting from human activities include biological (like virus, bacteria, fungi, protozoa and helminths) and physicochemical (nutrients, heavy metals and salts).

Contamination of groundwater with nitrate is a global problem. High levels of nitrate in groundwater not only may be a good indicator of groundwater contamination but also may lead to human and animal health problems. Information of sources, concentration, spatial and temporal distribution of nitrate in groundwater in Tanzania is uneven and limited; consequently, its quality remains poorly understood. The main objective of this study was to review various studies done in different areas of Tanzania so as to consolidate the existing scattered information on sources, concentration and trends of nitrate concentration in different aquifers. Such consolidated information will help the government to understand areas that require immediate attention/action. In addition, the information will help communities to avoid high-risk zones for further water sources (springs and wells) development and to limit practices that may threaten uncontaminated aquifer. Furthermore, the review will help policy makers and management personnel to use the information for a better groundwater management.

Tanzania: country profile

\section{Location}

Geographically, Tanzania is located in Eastern Africa between Latitude $1^{\circ}$ and $12^{\circ}$ South, and Longitude $29^{\circ}$ and $41^{\circ}$ East (Fig. 1). Tanzania borders with eight countries of Kenya, Uganda, Rwanda, Burundi, Democratic Republic of Kongo (DRC), Zambia, Malawi and Mozambique and to the eastern side by Indian Ocean. Landscape changes from East African Great Rift valley, narrow coastal plain, flat to slightly hilly central plateau, savannah landscape, steppe landscape and tropical forest.

\section{Population}

From 1968 to 2012, the population of Tanzania has tripled (NBS and Office of Chief Stastitian Zanzibar 2013). Tanzania is sparsely populated with average population density of 51 inhabitants per square kilometre (inh./sq. km) with interregional and urban-rural significant variations (NBS and Office of Chief Stastitian Zanzibar 2013). The population density in Tanzania mainland ranges from 13 to 3,133 inh./sq. km in Lindi and Dar Es Salaam, respectively, while for Tanzania Zanzibar it ranges from 135 to 2,581 inh./sq. km in Kusini Unguja and Mjini Magharibi, respectively (Fig. 2).

For the period of 2002 to 2012, Tanzania had average inter-censal population growth rate of $2.7 \%$ which is higher than estimated world's population growth rate of 
Fig. 1 Map of Tanzania, showing location, administration regional boundaries, major rivers and water basins

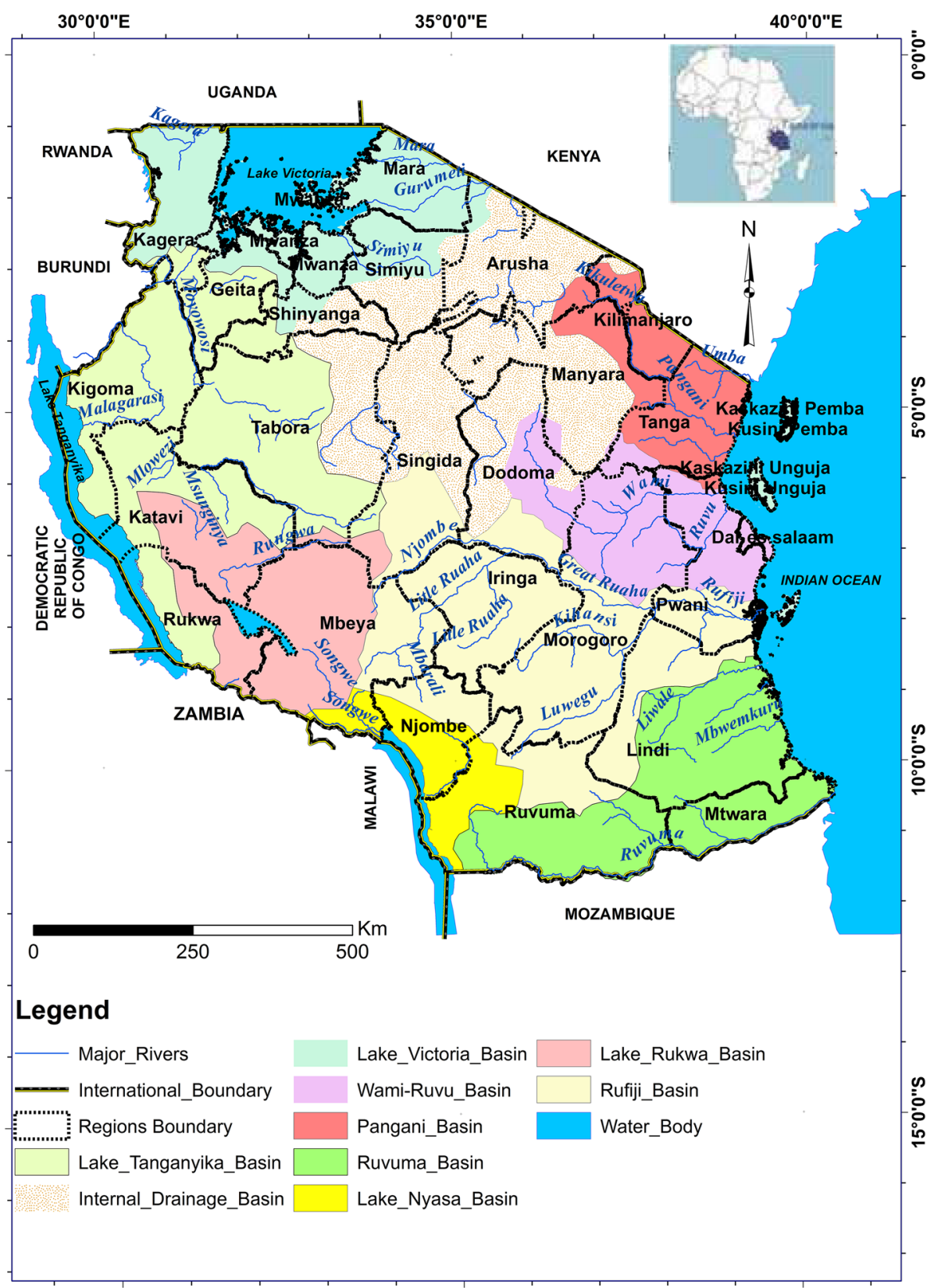

$0.77 \%$ for a period of 2000-2050 (UN 2004). However, there was a significant variation among regions (NBS and Office of Chief Stastitian Zanzibar 2013). Demands for water and threats to water resources are ever increasing owing to population growth and increased development of urban, peri-urban and rural communities.

\section{Climate}

Tanzania has a tropical climate with regional variations mainly modified by altitude. Temperature varies with seasons and altitude. In the highlands, temperature ranges from below 10 to $30{ }^{\circ} \mathrm{C}$ during cold and hot seasons, respectively, while the rest of the country has temperatures rarely falling lower than $20^{\circ} \mathrm{C}$ (McSweeney et al. 2014). Generally, the hottest period extends between November and February ( 25 to above $31{ }^{\circ} \mathrm{C}$ ), while the coldest period $\left(15-20{ }^{\circ} \mathrm{C}\right)$ occurs between May and August.

According to Nicholson (1996), Tanzanian climate is controlled by three major air streams and three convergence zones. The air streams include a humid Congo air with westerly and southwesterly flow, north east (NE) monsoon and south east (SE) monsoon. Westerly and southwesterly Congo air is separated by Congo air Boundary. Precipitation is controlled by the position of the Inter-Tropical Convergence Zone (ITCZ), which is relatively a narrow belt of very low pressure that forms near the earth's equator and monsoon wind pattern. ITCZ 
Fig. 2 Population density (inh./ sq. $\mathrm{km}$ ) of some selected regions compared to average national population density (NBS and Office of Chief Stastitian Zanzibar 2013)

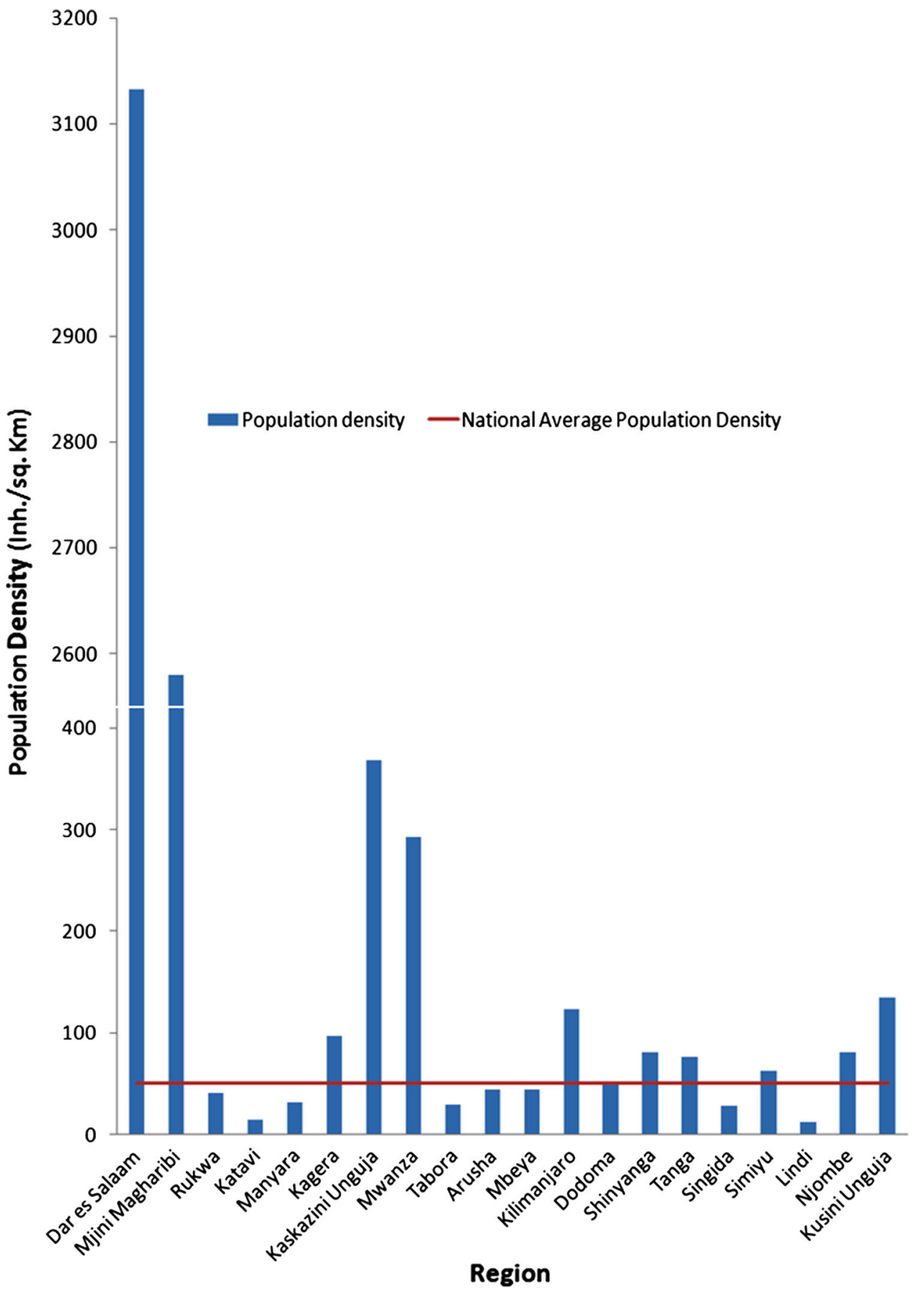

changes over the course of the year, migrating southwards through Tanzania in October to December, reaching the south of the country in January and February, and returning northwards in March, April and May (McSweeney et al. 2014). This causes areas around Lake Victoria basin (Nicholson 1996; Basalirwa et al. 1999; Tungaraza et al. 2012; McSweeney et al. 2014), western coast of the Indian Ocean (Sumner 1983; Nicholson 1996; McSweeney et al. 2014) and northern highlands (Nicholson 1996; Basalirwa et al. 1999; McSweeney et al. 2014) to experiences two distinct wet periods the 'short' rains (Vuli) in October to December and the 'long' rains (Masika) in March to May. The southern, western and central parts of the country experience one wet season from October to April/May, with central parts being relatively drier and others wet. The annual total rainfall ranges from less than $500 \mathrm{~mm}$ in central parts to more than $1,000 \mathrm{~mm}$ in wet areas, although the coastal regions and the Islands of Zanzibar and Pemba may receive about 1,500 $\mathrm{mm}$ (Sumner 1983; Nicholson 1996; Basalirwa et al. 1999; McSweeney et al. 2014). Such 
precipitation may facilitate groundwater recharge significantly if other factors like geology, geomorphology and land cover are good.

\section{Hydrogeology}

Geologically, Tanzania is studded by rocks that range in age from Precambrian to present (Howard 2011; Kashaigili 2012). These are grouped into hard formations (igneous and metamorphic rocks) and soft formation (sediments and sedimentary rocks). The ratio of soft to hard formation is approximated to be 1:3 (Kongola 2004). The hard formations of Tanzania include the Greenstone belt, Ubendian, Karagwe Ankolean, Bukoba, Usagaran and Mozambique systems. The greenstone belt of Tanzania is the oldest, forming the Tanzania Craton composed of Dodoman, Nyanzian and Kavirondian systems being intruded by granitoids. These formations host significant amount of groundwater mainly through fractures from the shallow depth $(<40 \mathrm{~m})$ to deep depth $(>100 \mathrm{~m})$ (Kashaigili 2012). Also, the Ubendian, Karagwe Ankolean, Bukoba, Usagaran and Mozambique systems, generally metamorphosed to high grade, host significant amount of groundwater through fractures. In these formations, the quality of groundwater has been affected significantly by the geology of the areas. For instance, there is high fluoride content in groundwater in Arusha, Manyara and Kilimanjaro regions due to dissolution of fluoride from fluoride bearing rocks of igneous origin (Ghiglieri et al. 2012).

The soft formations of Tanzania include the Mesozoic to Cenozoic sediments in the coastal areas, inland basins (mainly karoo sediments), rift valley sediments together with recent volcanic and fluvial sediments (Kashaigili 2012). Due to their primary porosity, sedimentary rocks are potential for accumulation of appreciable groundwater resource (Fetter 2001). Groundwater in the inland basins and rift system is controlled by both lithologies and structures; in some parts, the water quality is affected by the geology of the areas as in hard formations. Biogenic sedimentary deposits in the coastal and inland basins, e.g. Minjingu phosphate deposits formed during Pleistocene age probably, are the natural source of nitrate in the groundwater. However, their contributions to nitrate contamination in Tanzanian groundwater have not been established. The large part of the coastal sediments is affected by salinity. However, there are some areas with fresh groundwater, being hosted in sands, silts and fractured limestone.

Generally, groundwater storage in Tanzanian aquifers approximates $5,250 \mathrm{~km}^{3}$ (MacDonald et al. 2012). Nevertheless, the water yielding capacity of Tanzanian geological formations depends on their interstices and voids spaces. The quantitative information on potential of Tanzanian aquifer systems to yield groundwater is uneven and generally limited. Boreholes drilled for domestic water supplies indicate variable yields. Variable yields have been reported in boreholes drilled at different places of the country ranging from $<5$ to $>100 \mathrm{~m}^{3} / \mathrm{h}$ and averaging $11 \mathrm{~m}^{3} / \mathrm{h}$ (Baumann et al. 2005). An exceptionally high yield of about $460 \mathrm{~m}^{3} / \mathrm{h}$ was recorded in some boreholes in the Dodoma (Baumann et al. 2005).

The major source of groundwater in the aquifers of Tanzania is rainfall (Nkotagu 1996c; Rwebugisa 2008; Mjemah et al. 2011). In Tanzania, studies on the groundwater recharge potentials are limited. In Dodoma, where average rainfall is about $500 \mathrm{~mm} /$ year, recharge rate range from 5 to $10 \mathrm{~mm} /$ year, averaging to $1.3 \%$ of the annual rainfall (Rwebugisa 2008). On the other hand, the recharge in the Quaternary sand aquifer of Dar es Salaam ranged from 0 to $570 \mathrm{~mm} /$ year and averaging at $240.7 \mathrm{~mm} / \mathrm{year}$ for a period 1971-2006 (Mjemah et al. 2011). The amounts of groundwater in the aquifers are balanced with groundwater abstraction, base flow to rivers and discharge into the lakes and Indian Ocean.

\section{Land use}

Owing to population growth and human development, a significant amount of land has been converted from natural forests to settlements or agricultural land (Masanja 2003; Malugu 2007; Yanda and Munishi 2007; Kashaigili and Majaliwa 2010; Sheuya 2010; Mdemu et al. 2012). For example, due to population growth radius of built-up area in Dar es Salaam City expanded from $2 \mathrm{~km}$ in 1945 to $32 \mathrm{~km}$ northwards, $20-28 \mathrm{~km}$ westwards and $14 \mathrm{~km}$ southwards in 2002 (Sheuya 2010). In other parts of the country, for example, Malagarasi River catchment in Lake Tanganyika Basin there have been significant changes in land use where areas with settlements and cultivation have increased annually by $1.05 \%$ from 1984 to 2001 (Kashaigili and Majaliwa 2010). Similarly, land-use changes, from natural land to agricultural land and settlements particularly in the peri-urban areas, are on increase at an alarming rate in almost all urban centres in Tanzania (Kombe 2005). Such land uses in most cases have negative impact on the quality and quantity of the groundwater (Foster et al. 1999; Cronin et al. 2007).

\section{Hydrology and water resources management in Tanzania}

Tanzania Mainland has nine major drainage basins that are used as water resources management regimes (Fig. 1). Such basins include Lake Victoria, Pangani, Ruvu/Wami, Rufiji, Ruvuma and southern Coast, Lake Nyasa, Lake Tanganyika, internal drainage and Lake Rukwa basins. Within these river basins, there are several major rivers including Pangani, Wami, Ruvu, Rufiji, Mbwemkuru, 
Lukuledi, Malagarasi, Kagera and Ruvuma (Fig. 1). Also, great East African lakes, namely Lake Nyasa to the south, Lake Victoria in the north and Tanganyika to the west are found within these basins (Fig. 1). These rivers and other large water bodies are sources of water for various purposes such as irrigation, hydropower generation, industrial and domestic uses.

Access to safe drinking water in Tanzania is more pronounced in urban areas compared to rural areas. About $74 \%$ of urban households have access to safe drinking water as compared to about $40 \%$ of their rural counterparts (NBS and Office of Chief Stastitian Zanzibar 2013). Thus, about 26 and $60 \%$ of urban and rural populations, respectively, consume water of unknown quality. Water resources management in the drainage basins (Fig. 1) is undertaken by the Basin Water Office which is under the Basin Water Board (United Republic of Tanzania 2008). Boarders of each basin have been described by the Ministry of Water (United Republic of Tanzania 2008).

\section{Nitrate concentration in groundwater}

Nitrogen in the form of $\mathrm{NO}_{3}{ }^{-}, \mathrm{NO}_{2}{ }^{-}, \mathrm{NH}_{3}{ }^{+}$and organic nitrogen is one of the most common contaminants which may be found in the groundwater (Tredoux et al. 2000; Orebiyi et al. 2010). Nitrate is a compound of nitrogen that may occur naturally in very low concentrations in the groundwater. It is normally a stable compound especially in oxygen-rich environments. Nitrate is very soluble in water and is readily leached from soils dominated by permanent negative charges or soils with moderate to high $\mathrm{pH}$, without being influenced by adsorption and precipitation reactions. Nitrate can persist in groundwater for decades and accumulate to high levels as more nitrogen is applied to the land surface every year. Waters containing more than $50 \mathrm{mg} / \mathrm{l}$ of nitrate can lead to human and animal health problems (WHO 2007; Gatseva and Argirova 2008). Discharge of nitrate contaminated groundwater to water bodies with low nitrate concentrations may result in eutrophication (Spalding and Exner 1993). The presence of nitrate at elevated concentration in the groundwater may be an indirect indicator of the presence of other contaminants derived from human activities (Reynolds-Vargas et al. 2006). A full understanding of the natural concentration, possible sources and biogeochemical transformation of nitrate is required for a successful groundwater management strategy.

Background concentration of nitrate in groundwater

Determining the degree of nitrate contamination in the groundwater is difficult without a clear understanding of background concentrations present. Background concentrations of nitrate in different aquifers vary depending on geological formations and current and past vegetation cover (ECETOC 1988; Foster et al. 1999; West 2001; Limbrick 2003; Wendland et al. 2005). Natural sources of nitrate in the groundwater include leaching and oxidation of nitrogenous compounds incorporated in rocks (Holloway and Dahlgren 2002) and fixation by leguminous plants and microorganisms (Edmunds and Smedley 1996). According to Holloway and Dahlgren (2002), rock nitrogenous compound concentrations range from trace levels to above $200 \mathrm{mg}-\mathrm{N} / \mathrm{kg}$ in granites and may exceed 1,000 mg$\mathrm{N} / \mathrm{kg}$ in some sedimentary and meta-sedimentary rocks. In many aquifers, background concentration of nitrate is less than $1 \mathrm{mg} / \mathrm{l}$ (West 2001; Wendland et al. 2005). However, due to variation in geochemical and historical vegetation cover, higher background concentrations have been reported elsewhere (Burkart and Kolpin 1993; Eckhardt and Stackelberg 1995; Mueller 1995; Foster et al. 1999; Limbrick 2003). Such background concentration of nitrate may reach as high as $10 \mathrm{mg} / \mathrm{l}$ (Lawrence 1983; ECETOC 1988; Nishikawa et al. 2003; Panno et al. 2006).

In Tanzania, the background concentration of nitrate in the groundwater remains poorly understood. However, the limited data collected from various aquifers in undisturbed areas particularly protected areas, uncultivated areas and deep aquifers in Tanzania indicate a nitrate concentration of less than $2.5 \mathrm{mg} / \mathrm{l}$ (Rwebugisa 2008; Mckenzie et al. 2010; GITEC and WEMA 2011; Bakari et al. 2012). For example, Rwebugisa (2008) reported that nitrate was not detected even in shallow wells located in protected areas in Makutupora sub-basin in the Internal Drainage Basin. In addition, background concentration of nitrate in groundwater in Zanzibar is not well known although $5.0 \mathrm{mg} / \mathrm{l}$ have been considered as an indication of influence from sewage (Hansson 2010). Because background nitrate concentration in different aquifer systems in Tanzania remains poorly understood, the background nitrate concentration of $10 \mathrm{mg} / \mathrm{l}$ as used by Lawrence (1983), ECETOC (1988), Nishikawa et al. (2003) and Panno et al. (2006) was adopted in this review. Nevertheless, because the geology, climate and land use differ from one place to another, water basin-specific background concentration needs to be established.

Sources of nitrate in the groundwater

Nitrate leaching to groundwater is related to hydrogeological conditions, land use and soil type (Oenema et al. 2005). Intensive agriculture, domestic and industrial wastes disposal and atmospheric nitrogen contamination are considered to be the main sources of nitrate contamination in the groundwater (Goldberg 1989). Major sources of nitrate 
in urban aquifers are related to wastewater disposal (onsite systems particularly pit latrines and leaky sewers), solid waste disposal (dumpsites) and industrial activities (Bowell et al. 1997; Tredoux et al. 2000; Wakida and Lerner 2005; Mjemah et al. 2011; Mtoni et al. 2012). Human excreta introduces about $5 \mathrm{~kg}$ of nitrogen to the environment per year per capita (Lewis et al. 1980).

Agriculture is the main source of nitrate in groundwater from rural areas due to application of organic and inorganic fertilisers (Jalali 2005; Ju et al. 2006; Reynolds-Vargas et al. 2006; Srinivasamoorthy et al. 2009; Divya and Belagali 2012; Dragon 2012). Expansion of agricultural activities will be associated with increased use of fertilisers and pesticides. For example, although the use of fertilizer is quite low in Tanzania compared to other countries, it has been rising in recent years. The use of fertilizers increased from about 120,000 metric tons in $2005 / 06$ to 263,000 metric tons for the year 2009/10 (International Fertilizer Development Centre 2012). In such an increase, urea and diammonium phosphate (DAP) accounted for about half the total volume of 2010, NPK fertilizer which is mainly composed by nitrogen, phosphorus and potassium, consistently accounted for another $21 \%$ of the total, while calcium ammonium nitrate (CAN) accounted for approximately $9 \%$. Such fertilizers contain nitrogenous compounds which may be oxidised in the soil to nitrate and then leached to the aquifer. Furthermore, due to ambitious agricultural sector development plan (Kilimo Kwanza), the application of fertilizers is expected to rise from 263,000 to 574,000 metric tons in 2015 (International Fertilizer Development Centre 2012).

Nitrate from such sources can be introduced into groundwater systems by infiltration. Following periods of heavy rainfall, nitrate flushing can increase concentrations in both surface water and groundwater. Shallow aquifers are most susceptible to nitrate contamination as well as to other types of man-made contaminants. However, shallow aquifers far from human activities and in areas distant from the recharge zone may contain very low nitrate concentration.

\section{Nitrate contamination in Tanzanian groundwater}

\section{Study approach}

This paper consolidates information on nitrate concentrations and trends in groundwater from selected areas in different drainage basins in Tanzania. Data and information on spatial distribution, trends and concentrations of nitrate in groundwater at regional and local scales were gathered from previous studies. Previous studies on groundwater quality were limited to areas depending on the groundwater as the source of water supply and areas with poor water supply; therefore, groundwater sources are exploited to supplement shortage in water supply. The islands of Unguja and Pemba (Hansson 2010) and areas located in the Internal Drainage Basin mostly depends on the groundwater as the source of water supply (Kashaigili 2012), while some parts of Pangani basin, Wami/Ruvu basin and Lake Tanganyika basin use groundwater to supplement surface water supply (USFS 2009; GITEC and WEMA 2011; Mtoni 2013).

Nitrate concentrations in the groundwater $(\mathrm{mg} / \mathrm{l}$ as nitrate) were compared to a background concentration of $10 \mathrm{mg} / \mathrm{l}$ and WHO maximum allowable concentration $(50 \mathrm{mg} / \mathrm{l})$. The spatial distribution of nitrate was determined by plotting the relative concentration of nitrate on the map of Tanzania using ArcGIS 10 software. In addition, attempt to study a temporal trend of nitrate concentration in the groundwater was limited by the availability of continuous data.

Concentration and spatial distribution of nitrate in groundwater

\section{Concentration of nitrate in groundwater in the Internal Drainage Basin}

The Internal Drainage Basin is described by rivers/streams draining into a group of inland water bodies (lakes) that are located around the north-central part of the country. The Internal Drainage Basin runs southward from the border with Kenya to central Tanzania (Fig. 1). Groundwater is the main source of water for drinking, irrigation and industrial activities particularly in Singida (Bowell et al. 1997), Manyara (Bowell et al. 1997), Shinyanga (Bowell et al. 1997; Policy and Operations Evaluation Department (IOB) 2007), Arusha (Bowell et al. 1996, 1997; Pittalis 2010) and Dodoma (Nkotagu 1996a, b; Rwebugisa 2008) regions. Bowell et al. (1997) reported high nitrate concentration region reaching $180 \mathrm{mg} / \mathrm{l}$ which positively correlated significantly with coliform counts of the groundwater samples collected from Manyara and Arusha. Such high nitrate concentration associated with positive correlation with coliform counts reflects contamination originating from human and animal faecal matters.

The study by Nkotagu (1996a) showed that nitrate concentrations in groundwater samples collected from Hombolo sub-basin in Dodoma District (Fig. 3) ranged from 0.01 to $449.1 \mathrm{mg} / \mathrm{l}$ with a median of $52.8 \mathrm{mg} / 1.50 \%$ of the samples had nitrate concentration higher than the maximum concentration recommended for drinking water by WHO (2007), while $76 \%$ of the samples had nitrate concentrations above background concentration of $10 \mathrm{mg} /$ 1. Such data indicate that about $76 \%$ of the water samples were contaminated by nitrate resulting from human 


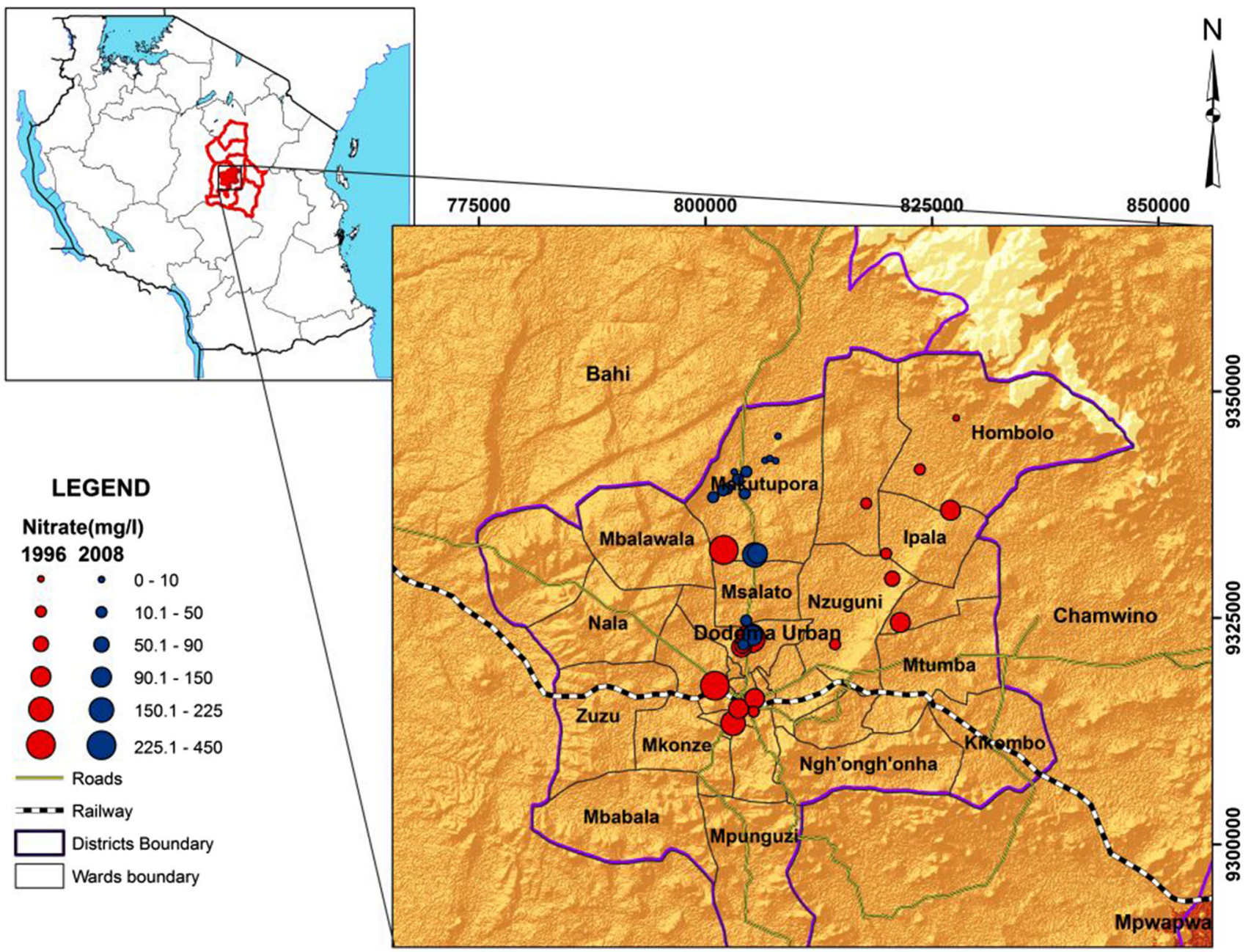

Fig. 3 Distribution of nitrate (mg/l) in groundwater in Dodoma District (source of data Rwebugisa 2008; Nkotagu 1996a)

activities specifically onsite sanitation (particularly pit latrines) and animal manure since the area is occupied by pastoralists, and there is no or insignificant application of industrial fertilizers. The significant negative correlation between nitrate concentration and $\mathrm{pH}$ was observed owing to mineralisation and nitrification of organic nitrogen from animal manure and/or human wastes in either the aquifer or unsaturated zone (Nkotagu 1996a).

Rwebugisa (2008) reported nitrate concentration ranging from 0.0 to $150 \mathrm{mg} / \mathrm{l}$ and median of $20 \mathrm{mg} / \mathrm{l}$ in groundwater samples collected from Makutupora, Msalato and Dodoma urban centre (Fig. 3). $18 \%$ of the groundwater samples had nitrate concentration higher than the maximum concentration recommended for drinking water by WHO (2007), while $55 \%$ of the samples had nitrate concentrations above background concentration of $10 \mathrm{mg} /$ 1. It was noted that the concentration of nitrate in protected areas (Makutupora) was low compared to the other areas (Fig. 3) where it ranged from 0.9 to $32 \mathrm{mg} / \mathrm{l}$ below the maximum concentration recommended for drinking water by WHO. Such low nitrate concentration in the groundwater samples collected from Makutupora where boreholes supplying water to Dodoma municipality and surrounding villages are located probably was a result of prohibition of human activities around the area.

Figure 4 presents the spatial distribution of nitrate concentration in Arusha region which partly covers Internal Drainage Basin (northern of Mount Meru) and Pangani Basin (South of Mt. Meru). Pittalis (2010) reported elevated nitrate concentration ranging from below detection to $72 \mathrm{mg} / \mathrm{l}$ in groundwater samples collected from Ngarenanyuki and Oldoinyo Sambu wards (Fig. 4) in 2007 with median of $24 \mathrm{mg} / \mathrm{l} .7 \%$ of the groundwater samples had nitrate concentration higher than the maximum concentration recommended for drinking water by WHO (2007), while $93 \%$ of the samples had nitrate concentrations above background concentration of $10 \mathrm{mg} / \mathrm{l}$. The elevated nitrate concentration in water sample collected from Ngarenanyuki and Oldoinyo Sambu probably indicates contamination mainly caused by agricultural activities. 


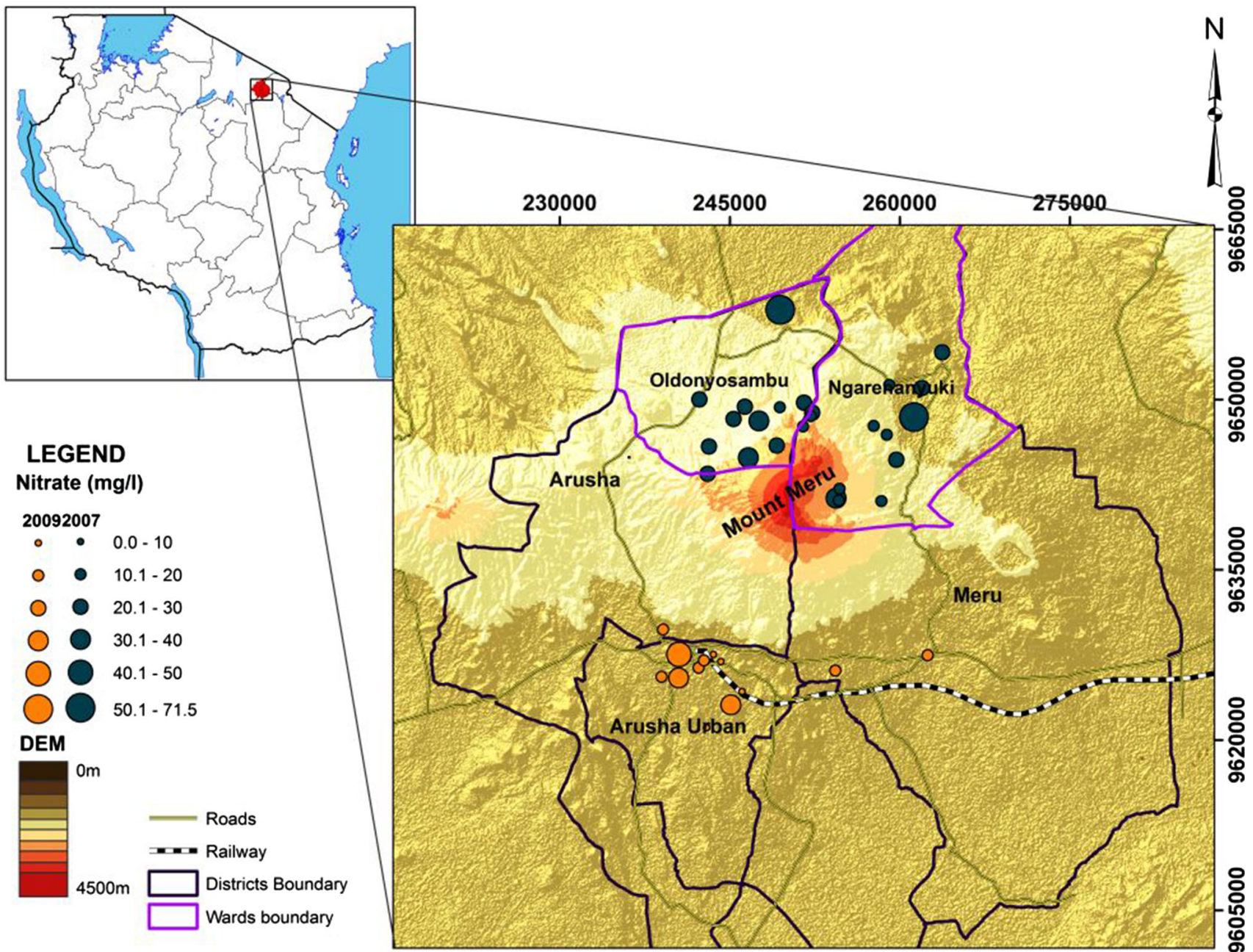

Fig. 4 Spatial distribution of nitrate (mg/l) in groundwater in part of Arusha region around Mount Meru (source of data Pittalis 2010; GITEC and WEMA 2011)

\section{Concentration of nitrate in groundwater in the Pangani Basin}

The Pangani Basin is located in the north-eastern Tanzania between latitude $3^{\circ} 03^{\prime} \mathrm{S}$ and $5^{\circ} 59^{\prime} \mathrm{S}$ and longitude $36^{\circ} 23^{\prime} \mathrm{E}$ and $39^{\circ} 13^{\prime} \mathrm{E}$ with an area of about $53,600 \mathrm{~km}^{2}$ (Fig. 1). Seventeen administrative districts of Arusha, Manyara, Kilimanjaro and Tanga regions are within the Pangani River Basin. The basin is composed of five sub-catchments, namely Pangani, Zigi, Umba, Mkulumuzi and Msangazi with main rivers draining to the Indian Ocean. Pangani River which is the largest river in the basin has two main tributaries, i.e. Ruvu and Kikuletwa which meet at Nyumba ya Mungu Dam. Major water use activities include hydropower production, small- and large-scale irrigation, and domestic and industrial water needs.

Elevated nitrate concentrations in groundwater in Pangani Basin have been reported by many authors (Mckenzie et al. 2010; Bowell et al. 1997; GITEC and WEMA 2011).
For example, Mckenzie et al. (2010) reported groundwater nitrate concentration ranging from below detection limits in undisturbed areas to $11.8 \mathrm{mg} / \mathrm{l}$ in cultivated areas around Mount Kilimanjaro. Furthermore, GITEC and WEMA (2011) reported nitrate concentration ranging between 4 and $47 \mathrm{mg} / \mathrm{l}$ and median of $11 \mathrm{mg} / \mathrm{l}$ in groundwater samples collected from southern part of Mount Meru in Arusha municipality (Fig. 4). All groundwater samples had nitrate concentration less than the maximum concentration recommended for drinking water by WHO (2007), while $60 \%$ of the samples had nitrate concentrations above background concentration of $10 \mathrm{mg} / \mathrm{l}$. Elevated nitrate concentration was observed within Arusha municipality (Fig. 4) probably originating from onsite sanitation facilities particularly pit latrines.

In Tanga region (Fig. 5), nitrate concentration in groundwater ranged between 0 and $747 \mathrm{mg} / \mathrm{l}$ with a median of $9 \mathrm{mg} / \mathrm{l}$ (GITEC and WEMA 2011). Fourteen percent of groundwater samples mostly from sources located in urban 


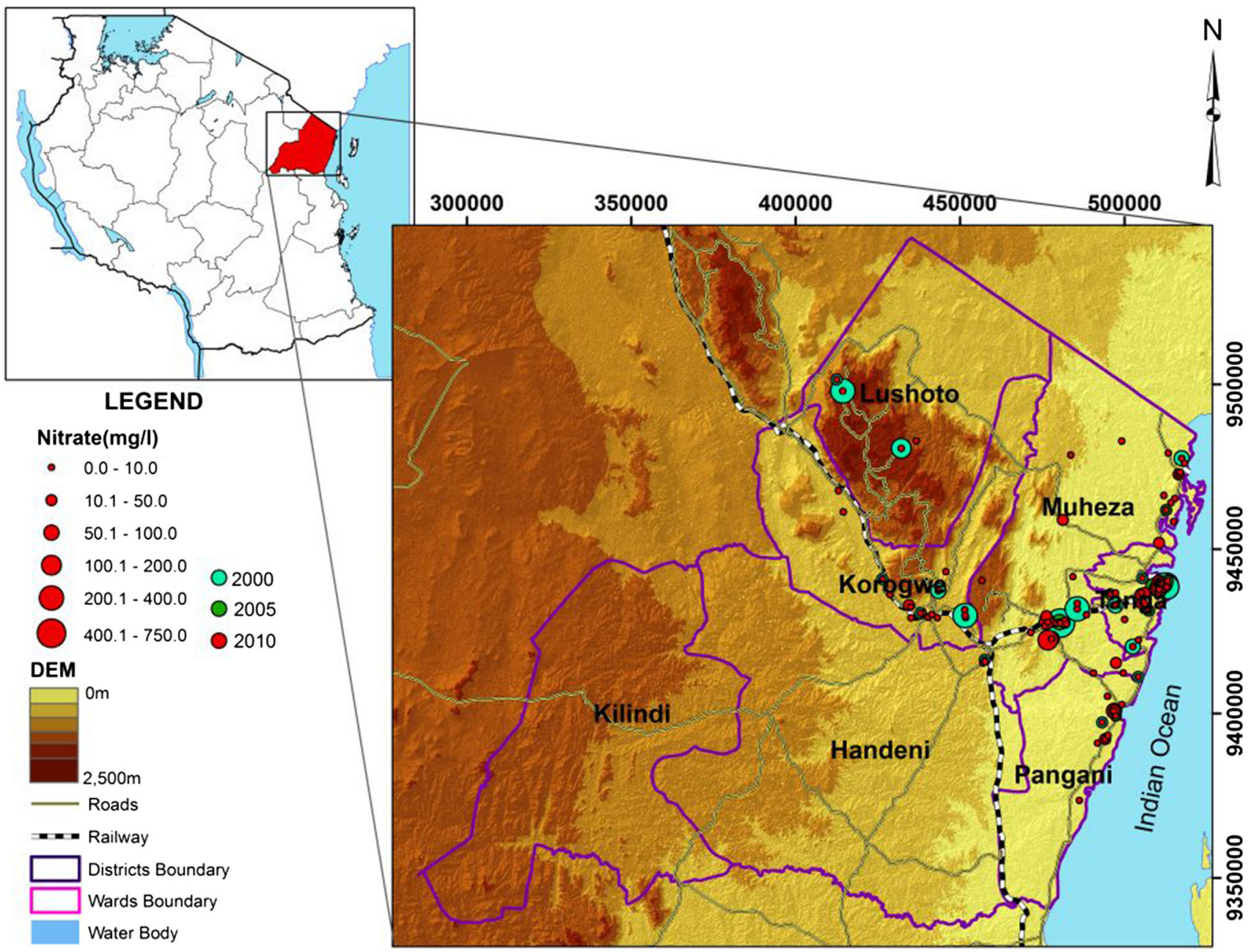

Fig. 5 Spatial distribution of nitrate $(\mathrm{mg} / \mathrm{l})$ in groundwater in part of Tanga region (GITEC and WEMA 2011)

areas had nitrate concentration higher than the maximum concentration recommended for drinking water by WHO (2007). Additionally, $45 \%$ of the samples had nitrate concentrations above background concentration of $10 \mathrm{mg} / \mathrm{l}$. Elevated nitrate concentration was observed in urban areas of Lushoto, Tanga and Korogwe (Fig. 5). Such elevated nitrate concentrations were associated with onsite sanitation facilities particularly pit latrines (GITEC and WEMA 2011).

\section{Concentration of nitrate in groundwater in the Wami-Ruvu Basin}

Wami/Ruvu basin consists of two main river systems, the Wami and the Ruvu and some small coastal rivers (e.g. Msimbazi, Kizinga and Mzinga rivers) in the south of Dar es Salaam (Fig. 1). The Wami-Ruvu Basin is one of the four basins that drain into the Indian Ocean. Wami-Ruvu Basin covers parts of Dodoma, Morogoro, Tanga, Coast and Dar es Salaam regions (Fig. 1). Dares Salaam City, which is the highly populated urban area in Tanzania, receives piped water from Ruvu and Mzinga rivers. However, due to increasing water demand, poor infrastructures, and deteriorating quality and quantity of river water, surface water supply from Ruvu and Mzinga rivers does not suffice the water requirements for Dar es Salaam City (Mtoni 2013). To supplement surface water, significant number of wells and boreholes has been developed by different organizations and individuals in Dar es Salaam (Mato 2002; Bakari et al. 2012; Mjemah et al. 2012; Mtoni et al. 2013) and Morogoro (Kibona et al. 2011).

Spatial distribution of nitrate observed at different time in the groundwater in Dar es Salaam is presented in Fig. 6. Nitrate concentration showed a decreasing trend as one moves from the city centre to periphery especially to western direction owing to decreasing population density. Nitrate concentration in groundwater of Dar es Salaam ranged from below detection limit to more than $445 \mathrm{mg} / \mathrm{l}$ (Mato 2002; Mjemah 2007; Napacho and Manyele 2010; Dejager 2011; Bakari et al. 2012; De Witte 2012; Mtoni et al. 2013) with highest observable at Mbagala (Bakari 


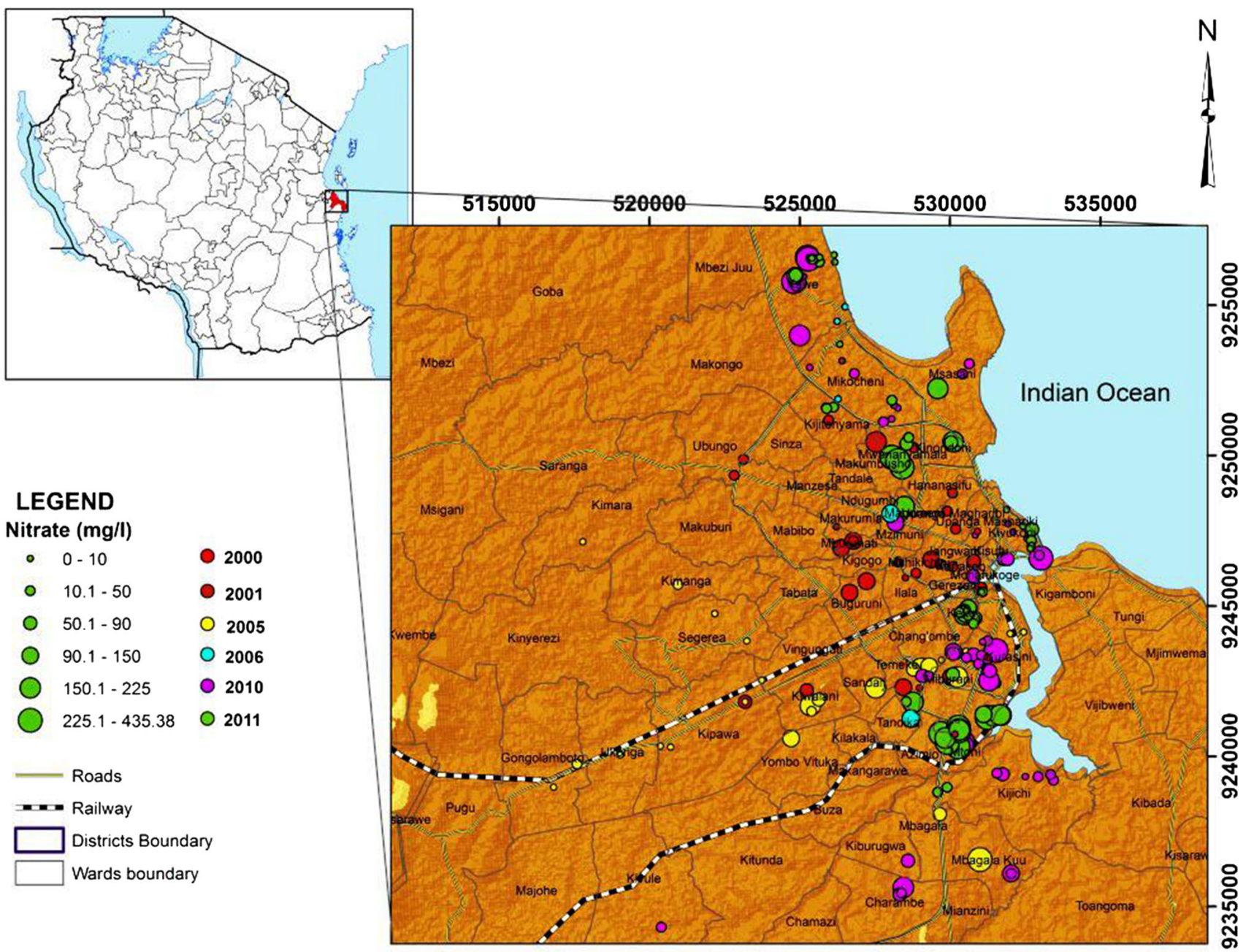

Fig. 6 Spatial distribution of nitrate (mg/l) in groundwater in some parts of Dar es Salaam City (Mato 2002; Mjemah 2007; Mtoni 2013)

et al. 2012). Highest recorded nitrate concentration in Chang'ombe, Mtoni, city centre and Kawe were 318, 213, 424 and $435 \mathrm{mg} / \mathrm{l}$, respectively (Fig. 6). Elevated concentration of nitrate was observed in both shallow and deep wells with shallow wells having the highest concentration relative to that of deep wells (Mtoni et al. 2013). Generally, $32 \%$ of groundwater samples collected in Dar es Salaam from 2000 to 2011 had nitrate concentration higher than the maximum concentration recommended for drinking water by WHO (2007). Furthermore, $60 \%$ of the samples had nitrate concentrations above background concentration of $10 \mathrm{mg} / \mathrm{l}$. Elevated concentration of nitrate in the groundwater samples collected from the city centre was associated with the leakage of untreated sewage owing to the lack of rehabilitation of ageing sewage system (Mtoni et al. 2013). On the other hand, such elevated concentration was the result of the presence of high to very high density of septic tanks and pit latrines, respectively, in areas not connected to sewage pipe like Kawe, Mbagala, Chang'ombe and Mtoni (Mato 2002; Mjemah 2007; Napacho and Manyele
2010; Bakari et al. 2012; Mtoni et al. 2013). This is a serious problem because in Dar es Salaam City, groundwater consumption is increasing at an alarming rate due to dwindling of water supply services (Mtoni et al. 2013).

According to Kibona et al. (2011), nitrate concentrations of groundwater within the Morogoro municipality ranged from 1.4 to $32.5 \mathrm{mg} / \mathrm{l}$ where wells that are less than $40 \mathrm{~m}$ deep had higher values. Almost $25 \%$ of reported wells had nitrate concentration above $10 \mathrm{mg} / \mathrm{l}$. Kilakala, the most densely populated area, had highest nitrate concentration relative to other areas (Fig. 7).

\section{Concentration of nitrate in groundwater in the Lake Tanganyika Basin}

Lake Tanganyika Basin is situated in the western part of the country. The basin covers a total of $239,000 \mathrm{~km}^{2}$ from Tanzania, Rwanda, Burundi, Democratic Republic of Congo and Zambia (Fig. 1). Almost $60 \%$ of the total runoff to Lake Tanganyika is from Tanzanian side. In the 


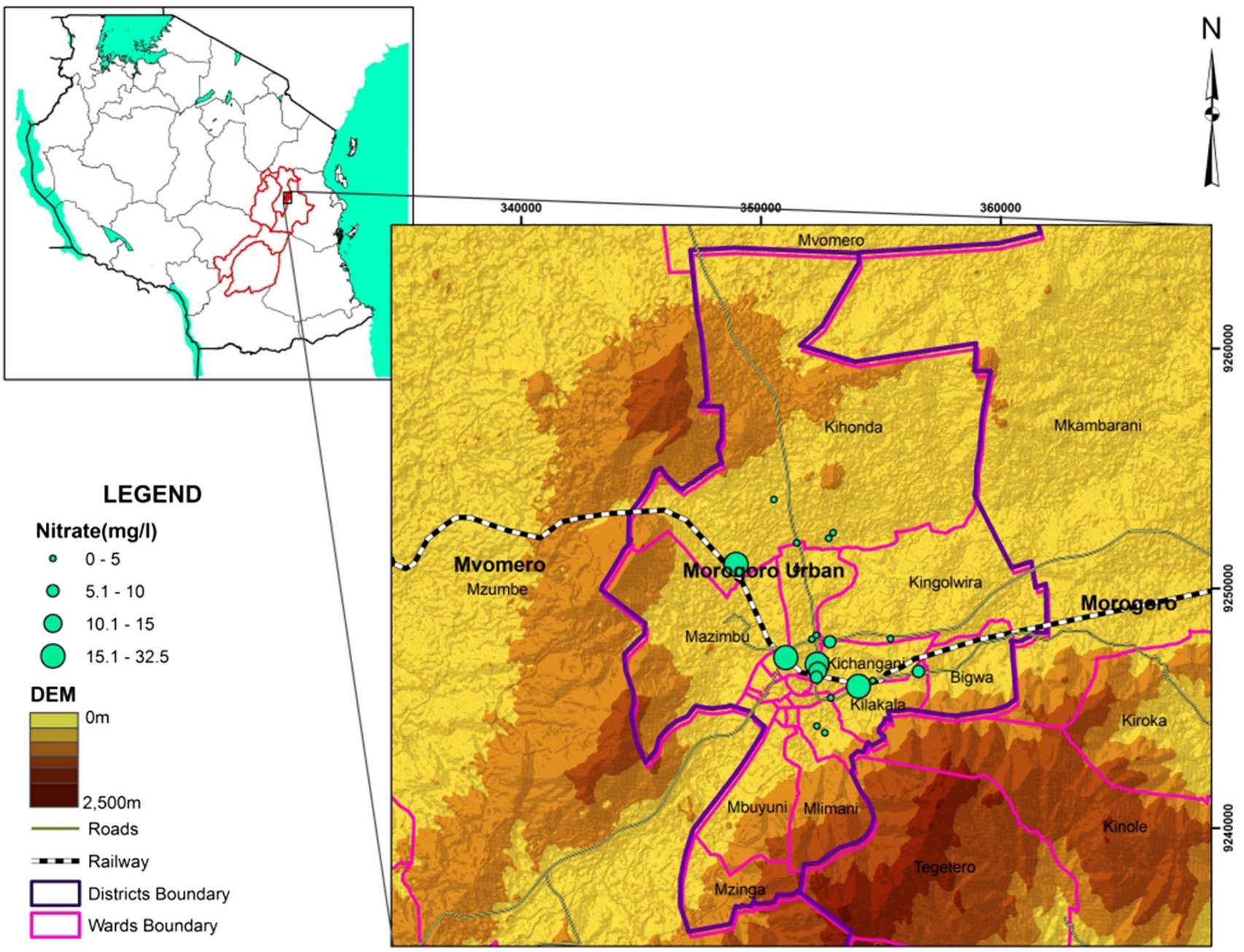

Fig. 7 Spatial distribution of nitrate $(\mathrm{mg} / \mathrm{l})$ in groundwater within the Morogoro municipality (Kibona et al. 2011)

Tanzanian side, agriculture and livestock keeping are the main economic activities (United Republic of Tanzania 2008; Jögensen et al. 2006). USFS (2009) reported elevated levels of nitrate in the groundwater above background concentration of $10 \mathrm{mg} / \mathrm{l}$ ranging from below detection limit to $94.2 \mathrm{mg} / \mathrm{l}$ in Tabora, which indicates groundwater contamination. Such elevated levels of nitrate concentration in groundwater are probably caused by agricultural activities.

\section{Concentration of nitrate in groundwater Zanzibar}

Information on the levels of nitrate and ammonia in groundwater, which is the main source of drinking water in Zanzibar, is scarce (Gössling 2001; Hansson 2010). A few of the reported works showed that the levels of nitrate are not higher than $10 \mathrm{mg} / \mathrm{l}$ (Hansson 2010). Although the reported nitrate concentrations values in drinking water are below the toxic level, they are, however, higher than the proposed background concentration for Zanzibar of $5.0 \mathrm{mg} / \mathrm{l}$ (Hansson 2010). This could be a signal of anthropogenic contamination, and if immediate actions are not taken, the levels could increase abruptly parallel to the increase in human population. Onsite sanitation facilities (most households use pit latrines while most hotels use soak-pits) are the main source of nitrate (Hansson 2010). There is a high positive correlation between nitrate and ammonia concentration which may indicate that it is very likely that the ammonia and the nitrate come from the same source (Hansson 2010).

\section{Variation of Nitrate concentration with depth}

Variation of nitrate concentration with depth depends on the land use, climate, hydrogeology, biological composition and physicochemical properties of the area. Mtoni 
(2013) reported a decreasing trend of nitrate concentration in groundwater as the depth of the well increased. It was observed that nitrate concentration increased from below $10 \mathrm{~m}$ reaching a maximum at between 15 and $20 \mathrm{~m}$ deep then decreasing. Furthermore, Kibona et al. (2011) observed a significant negative correlation $(r=-0.8734$, $p<0.01$ ) between nitrate concentration and well depth where highest concentration of nitrate $(32.5 \mathrm{mg} / \mathrm{l})$ was observed in wells of less than $35 \mathrm{~m}$ deep decreasing gradually to $1.4 \mathrm{mg} / \mathrm{l}$ at a depth of $65 \mathrm{~m}$. The decrease in nitrate concentration with depth can be attributed to the anoxic condition common in deep wells. In anoxic condition, nitrate will be the electron acceptor of choice, hence easily reduced. With little or no oxygen, microorganisms use nitrate as an electron acceptor to oxidise organic carbon. In doing so, nitrate concentration is lowered or depleted.

Trends in nitrate concentrations in the groundwater in Tanzania

The degree of nitrate contamination in groundwater is mainly a function of past and present land use. Trends in nitrate concentration in the groundwater require long-term records of a particular aquifer. However, in Tanzania such records are missing, and there is a discontinuity of the information. For example, nitrate concentration in some wells/boreholes in Makutupora Dodoma increased from natural concentration of $0.1-10 \mathrm{mg} / \mathrm{l}$ in 1983 to above $100 \mathrm{mg} / \mathrm{l}$ in 2004 (Rwebugisa 2008). Furthermore, the average concentration of nitrate in protected Makutupora well field have been gradually increasing from an average of $0.85 \mathrm{mg} / \mathrm{l}$ in 1983 to an average of $31.87 \mathrm{mg} / \mathrm{l}$ in 2004 (Fig. 8). Similar trends can be derived from few studies conducted in Dar es Salaam. The study conducted by Mato (2002) in Dar es Salaam in 2001/02 reported high values of nitrates concentration in groundwater of up to $151 \mathrm{mg} / \mathrm{l}$. About 5 years later, Mjemah (2007) reported a maximum value of nitrate of $421 \mathrm{mg} / \mathrm{l}$ 2005/06. Furthermore, Mtoni et al. (2012) and Bakari et al. (2012) reported 435.4 and $445 \mathrm{mg} / \mathrm{l}$, respectively, in Dar es Salaam in 2010/11. The trend indicates that the concentration of nitrate in groundwater in Dar es Salaam is increasing with time although this observation cannot be conclusive because the values indicated above may not be of samples from the same boreholes.

Specifically, some few wells in Dar es Salaam exhibited significant changes in nitrate concentration with time (Fig. 9; Table 1). The data from such studies indicate an increase in nitrate with time (Table 1). Such an increase in nitrate concentration in the groundwater in Dar es Salaam

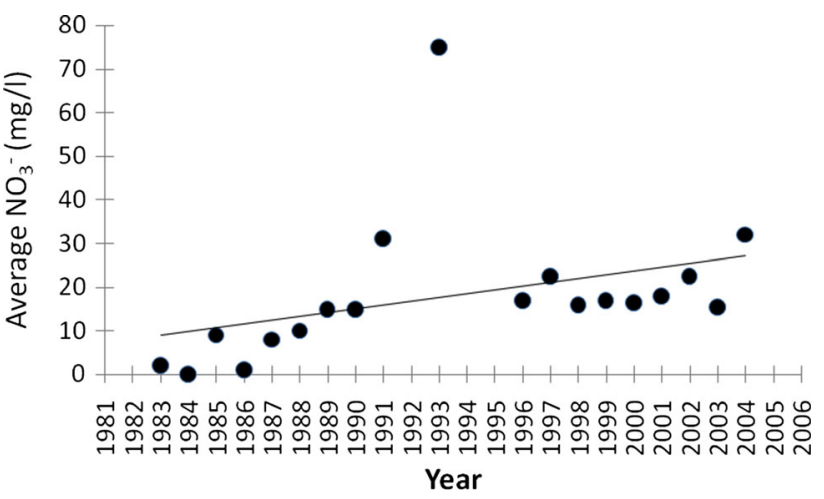

Fig. 8 Trends of average nitrate concentration $(\mathrm{mg} / \mathrm{l})$ in groundwater from MakutuporaB from 1983 to 2004 [source Rwebugisa (2008)]

Table 1 Boreholes displaying increasing or decreasing trends of nitrate concentrations (mg/l) in Dar es Salaam, Tanzania

\begin{tabular}{llll}
\hline $\begin{array}{l}\text { Borehole } \\
\text { no. }\end{array}$ & $\begin{array}{l}\mathrm{NO}_{3}{ }^{-} \\
(\mathrm{mg} / \mathrm{l})\end{array}$ & $\begin{array}{l}\text { Time of } \\
\text { collection }\end{array}$ & References \\
\hline $66 / 98$ & 18.3 & 2000 & Mato (2002) \\
& 97.7 & 2001 & Mato (2002) \\
$27 / 97$ & 108.0 & 2001 & Mato (2002) \\
& 167.2 & 2005 & Mjemah (2007) \\
$12 / 97$ & 1.6 & 2001 & Mato (2002) \\
& 78.2 & 2005 & Mjemah (2007) \\
$164 / 99$ & 55.5 & 2001 & Mato (2002) \\
& 78.7 & 2005 & Mjemah (2007) \\
$275 / 97$ & 19.9 & 2001 & Mato (2002) \\
& 53.4 & 2010 & Dejager (2011) \\
$99 / 98$ & 1.4 & 2000 & Mato (2002) \\
& 36.6 & 2001 & Mato (2002) \\
$142 / 98$ & 9.0 & 2005 & Mjemah (2007) \\
& 42.9 & 2010 & Napacho and Manyele \\
& & & (2010) \\
$39 / 98$ & 14.6 & 2000 & Mato (2002) \\
& 97.7 & 2001 & Mato (2002) \\
$59 / 97$ & 62.2 & 2001 & Mato (2002) \\
& 0.5 & 2005 & Mjemah (2007) \\
\hline
\end{tabular}

was probably caused by population increase, which leads to increase in onsite sanitation facilities particularly pit latrines. However, significant decreases in nitrate concentration have been observed in some wells/boreholes. For example, nitrate concentration in borehole number 59/97 (Fig. 9) in Dar es Salaam decreased significantly from 2001 to 2005 (Table 1). Also, Rwebugisa (2008) reported decrease in nitrate concentration in some wells in Makutupora well field due to efforts to protect the well field area from impacts of human activities associated with shifting of people to other areas. 
Fig. 9 Map showing locations of boreholes (Table 1) (with increasing or decreasing trends in nitrate $\mathrm{mg} / \mathrm{l}$ )

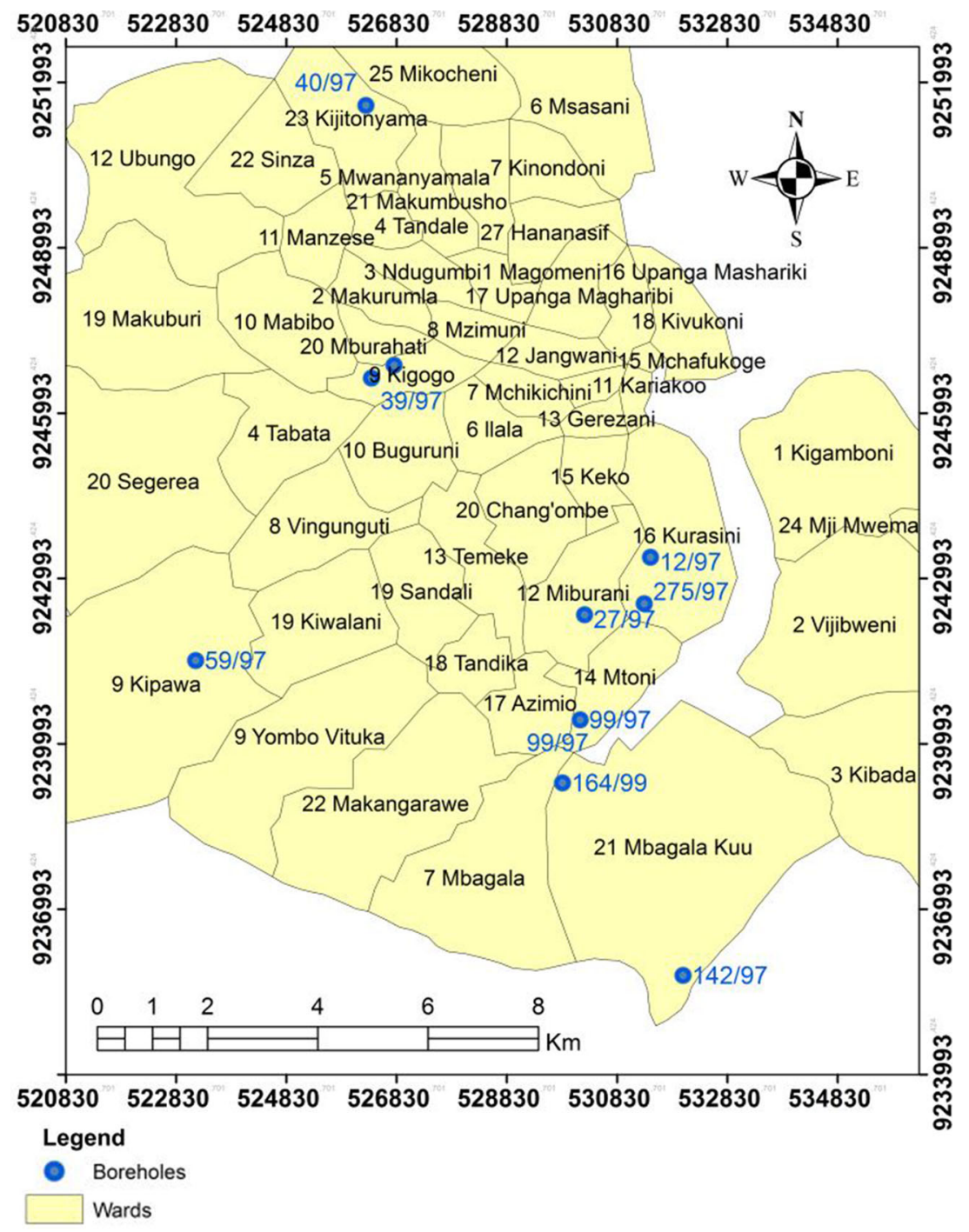

\section{Conclusion}

Concentration of nitrate in groundwater in many parts of Tanzania is above the background level of $10 \mathrm{mg} / \mathrm{l}$ and in some places exceeds WHO maximum recommended levels for drinking water. Highest values were observed in urban areas of Dar es Salaam, Dodoma and Tanga where the concentration of nitrate in some aquifers was higher than $400 \mathrm{mg} / \mathrm{l}$. Nitrate concentration in internal basin is high particularly in Hombolo sub-basin, Dodoma, where the values of nitrate concentration are as high as $449 \mathrm{mg} / \mathrm{l}$. Similarly, high concentration of nitrate $(445 \mathrm{mg} / \mathrm{l})$ was observed within the city of Dar es Salaam. High nitrate concentrations in groundwater samples from urban areas like Arusha, Dar es Salaam, Dodoma and Tanga most likely result from contamination from sanitation systems particularly pit latrines. Generally, in urban areas, concentration of nitrate in groundwater samples decreased as one moved from densely populated areas to sparsely populated areas probably due to decreasing density of sanitation facilities. In rural settings, elevated nitrate concentration in the groundwater probably was contributed by excessive use of fertilisers (inorganic fertilizers and animal manure). Coverage of reported nitrate values in groundwater is unevenly distributed with large part of the country lacking reported nitrate values. This calls for deliberate move to determine nitrate concentration in groundwater throughout the country so as to establish background levels of nitrate and build-up database for future use and reference. Multiple potential sources of nitrate were observed which calls for further research to trace the source of nitrate so as to ascertain the actual source of nitrate. Immediate measures are required to stop the current trend of groundwater contamination through protection of recharge basins and improve onsite sanitation systems.

Acknowledgments The authors wish to acknowledge Government of Tanzania through The Nelson Mandela, African Institution of 
Science and Technology (NM-AIST), for funding this study. Also we wish to give our sincere thanks to anonymous reviewers for their constructive comments.

Conflict of interest There is no any conflict of interest.

Open Access This article is distributed under the terms of the Creative Commons Attribution License which permits any use, distribution, and reproduction in any medium, provided the original author(s) and the source are credited.

\section{References}

Baird C (1995) Environmental chemistry. W.H. Freeman and Co, USA Bakari SS, Aagaard P, Vogt RD, Ruden F, Johansen I, Vuai SA (2012) Delineation of groundwater provenance in a coastal aquifer using statistical and isotopic methods, Southeast Tanzania. Environ Earth Sci 66:889-902

Basalirwa CPK, Odiyo JO, Mngodo RJ, Mpeta EJ (1999) The climatological regions of Tanzania based on the rainfall characteristics. Int J Climatol 19:69-80

Baumann E, Ball P, Beyene A (2005) Rationalization of Drilling Operations in Tanzania Review of the Borehole Drilling Sector in Tanzania. Report. p 51. http://www.sswm.info/sites/default/ files/reference_attachments/BAUMANN\%20et\%20al\%202005\% 20Rationalization $\% 20$ of\%20Drilling $\% 20$ Operations $\% 20 \mathrm{in} \% 20$ Tanzania.pdf. Accessed on 28 August 2014

Bowell RJ, McEldowney S, Warren A, Mathew B, Bwankuzo M (1996) Biogeochemical factors affecting groundwater quality in central Tanzania. In: Appleton JD, Fuge, R and McCall JH (eds) Environmental Geochemistry and Health: Geological Society, London, Special Publications No. 113. Geological Society of London, London, pp 107-130

Bowell RJ, Robertson S, Walles K, Bwankuzo MA, Cowan J, Kimaro N, Mjengera HA, Terkhell K, Warren A, Wood A (1997) Improving water quality assessment and supply. In: Pickford, J (ed) Water and Sanitation for All: Partnerships and innovations. Proceedings of the 23rd WEDC Conference, Durban, South Africa, pp 146-149

Brindha K, Elango L (2011) Fluoride in Groundwater: causes, implications and mitigation measures. In: Monroy SD (ed) Fluoride properties, applications and environmental management. Nova Publishers, New York, pp 111-136

Burkart MR, Kolpin DW (1993) Hydrologic and land-use factors associated with herbicides and nitrate in near-surface aquifers. J Environ Qual 22:646-656

Carol ES, Kruse EE, Laurencena PC, Rojo A, Deluchi MH (2012) Ionic exchange in groundwater hydrochemical evolution. Study case: the drainage basin of El Pescado creek (Buenos Aires province, Argentina). Environ Earth Sci 65:421-428

Cronin A, Pedley S, Hoadley A, Haldin L, Gibson J, Breslin N (2007) Urbanisation effects on groundwater chemical quality: findings focusing on the nitrate problem from 2 African cities reliant on on-site sanitation. J Water Health 5:441-454

De Witte I (2012) Characterization of the status of Dar es Salaam aquifer in view of salt-water intrusion and nitrate contamination, University of Gent

Dejager N (2011) Groundwater characterisation of a coastal aquifer in Dar es Salaam, Tanzania: identification of sources of groundwater contamination, University Gent

Divya J, Belagali SL (2012) Impact of chemical fertilizers on water quality in selected agricultural areas of Mysore district, Karnataka, India. Int J Environ Sci 2:1449-1458
Dragon K (2012) The changes of groundwater chemistry of semiconfined buried valley aquifer during one decade of water exploitation. Environ Earth Sci 65:1283-1290

ECETOC (1988) Nitrate and drinking water. Brussels, European Centre for Ecotoxicology and Toxicology of Chemicals (Technical Report No. 27). No. Technical Report No. 27, 250 Avenue Louise (Bte 63), 1050-Brussels, Belgium

Eckhardt DA, Stackelberg PE (1995) Relation of groundwater quality to land use on long Island, New York. Groundwater 33:1019-1033

Edmunds WM, Smedley PL (1996) Groundwater geochemistry and health: an overview. Geol Soc Lond Spec Publ 113:91-105

Fetter CW (2001) Applied hydrogeology, 4th edn. Prentice-Hall Inc., Upper Saddle River, p 612

Foster SSD, Morris BL, Chilton PJ (1999) Groundwater in urban development-a review of linkages and concerns. In: Ellis JB (ed) Proceedings of an International Symposium Held During IUGG 99, the XXII General Assembly of the International Union of Geodesy and Geophysics, at Birmingham, UK 18-30 July 1999. IAHS publication No. 259, Birmingham, UK, pp 3-12

Gatseva PD, Argirova MD (2008) High-nitrate levels in drinking water may be a risk factor for thyroid dysfunction in children and pregnant women living in rural Bulgarian areas. Int J Hyg Environ Health 211:555-559

Ghiglieri G, Pittalis D, Cerri G, Oggiano G (2012) Hydrogeology and hydrogeochemistry of an alkaline volcanic area: the NE Mt. Meru slope (East African Rift Northern Tanzania). Hydrol Earth Syst Sci 16:529-541

GITEC and WEMA (2011) Groundwater Assessment of the Pangani Basin, Tanzania. The Pangani BasinWater Board (PBWB) and the International Union for Conservation of Nature (IUCN) Report

Goldberg VM (1989) Groundwater pollution by nitrates from livestock wastes. Environ Health Perspect 83:25-29

Gössling S (2001) The consequences of tourism for sustainable water use on a tropical island: Zanzibar, Tanzania. J Environ Manag 61:179-191

Goulding K (2000) Nitrate leaching from arable and horticultural land. Soil Use Manag 16:145-151

Hansson E (2010) Groundwater on Zanzibar-use and contaminants. University of Goteborg, Sweden

Holloway JM, Dahlgren RA (2002) Nitrogen in rock: occurrences and biogeochemical implications. Glob Biogeochem Cycles 16:65 $(1-17)$

Howard AE (2011) A brief introduction to the geology and mining industry of Tanzania. A report prepared for Sika Resources Inc.Toronto, Ontario, p 15. http://sikaresources.com/wp-content/ uploads/2011/09/Tanzania-Backgrounder.pdf. Accessed on 10/12/ 2014

International Fertilizer Development Centre (2012) 'Tanzania Fertlizer Assessment Report. p 51. www.ifdc.org. Accessed on 23/11/2013

Jalali M (2005) Nitrates leaching from agricultural land in Hamadan, western Iran. Agric Ecosyst Environ 110:210-218

Jiang Y, Wu Y, Groves C, Yuan D, Kambesis P (2009) Natural and anthropogenic factors affecting the groundwater quality in the Nandong karst underground river system in Yunan, China. J Contam Hydrol 109:49-61

JICA (2002) The Study on the National Irrigation Master Plan in the United Republic of Tanzania. MASTER PLAN, vol 1-Main Report. Ministry of Agriculture and Food Security. Nippon Koei Company, Limited

Jögensen SE, Ntakimazi G, Kayombo S (2006) Lake Tanganyika: Experiences and Lesson Learned Brief. International Waters Learning Exchange and Resources Network, pp 363-375. http:// iwlearn.net/iw-projects/1665/experience-notes-and-lessons-learned/ laketanganyika_2005.pdf/view. Accessed 28 Aug 2014 
Ju XT, Kou CL, Zhang FS, Christie P (2006) Nitrogen balance and groundwater nitrate contamination: comparison among three intensive cropping systems on the North China Plain. Environ Pollut 143:117-125

Kaseva M (2006) Optimization of regenerated bone char for fluoride removal in drinking water: a case study in Tanzania. J Water Health 4:139-147

Kashaigili JJ (2012) Tanzania. In: Pavelic P Giordano M, Keraita B, Ramesh V, Rao T (eds.) Groundwater availability and use in Sub-Saharan Africa: A review of 15 countries. International Water Management Institute, PO Box No. 2075, 127, Sunil Mawatha, Pelawatte, Battaramulla, Sri Lanka, pp 195-216. http://www.iwmi.cgiar.org

Kashaigili JJ, Majaliwa AM (2010) Integrated assessment of land use and cover changes in the Malagarasi river catchment in Tanzania. Phys Chem Earth Parts A/B/C 35:730-741

Kibona I, Mkoma SL, Mjemah IC (2011) Nitrate pollution of Neogene alluvium aquifer in Morogoro municipality, Tanzania. Int J Biol Chem Sci 5:171-179

Kiptum CK, Ndambuki JM (2012) Well water contamination by pit latrines: a case study of Langas. Int J Water Resour Environ Eng 4:35-43

Kombe WJ (2005) Land use dynamics in peri-urban areas and their implications on the urban growth and form: the case of Dar es Salaam, Tanzania. Habitat Int 29:113-135

Kongola LRE (2004) Status of groundwater resource in Tanzania. A paper presented in the Annual General Conference of the Tanzania Geological Society (T.G.S), Mwanza, 1st-3rd July, 2004, p 18

Lawrence, C.R. (1983) Nitrate-rich groundwaters of Australia. Australian Water Resources Council, Technical Paper No. 79. Australian Government Publishing Service, Canberra. 110 pp. http://trove.nla.gov.au/work/21229344?q\&versionId=45478574. Accessed on 12/07/2014

Lewis WJ, Farr JL, Foster SS (1980) The pollution hazard to village water supplies in eastern Botswana. ICE Proc 69:281-293

Limbrick KJ (2003) Baseline nitrate concentration in groundwater of the Chalk in south Dorset, UK. Sci Total Environ 314-316:89-98

MacDonald AM, Calow RC (2009) Developing groundwater for secure rural water supplies in Africa. Desalination 248:546-556

MacDonald AM, Bonsor HC, Dochartaigh BÉÓ, Taylor RG (2012) Quantitative maps of groundwater resources in Africa. Environ Res Lett 7:024009

Malugu IO (2007) Resource-use conflicts and management challenges for Pugu and Kazimzumbwi forest reserves in Kisarawe and Ilala districts, Tanzania. Discov Innov 19:149-174

Masanja AL (2003) Drivers of Land Use Changes in Peri-Urban Areas of Dar es Salaam City, Tanzania: Paper Prepared for Presentation at the Open Meeting of the Global Environmental Change Research Community, Montreal, Canada, 16-18 October, 2003. In: Open Meeting of the Global Environmental Change Research Community, Montreal, Canada, 16-18 October, 2003, p 14

Mato RRAM (2002) Groundwater pollution in urban Dar es Salaam. Technical University of Eindhoven, Tanzania

Mckenzie JM, Mark BG, Thompson LG, Schotterer U, Lin PN (2010) A hydrogeochemical survey of Kilimanjaro (Tanzania): implications for water sources and ages. Hydrogeol J 18:985-995

McSweeney C, New M, and Lizcano G (2014) UNDP Climate Change Country Profiles: Tanzania, 1-27. http://www.geog.ox.ac. uk/research/climate/projects/undp-cp/UNDP_reports/Tanzania/ Tanzania.lowres.report.pdf. Accessed from 14/12/2014

Mdemu M, Kashaigili JJ, Lupala J, Levira P, Liwenga E, Nduganda A, Mwakapuja F (2012) Dynamics of land use and land cover changes in the Pugu and Kazimzumbwi forest reserves. CCIAM CCIAM Programme in Tanzania; 2nd to 3rd. January, 2012. http://www.taccire.suanet.ac.tz/xmlui/handle/123456789/74?show= full. Accessed 21 June 2014

Mjemah IC (2007) Hydrogeological and hydrogeochemical investigation of a coastal aquifer in Dar-es-Salaam. University of Gent, Belgium

Mjemah IC, Van Camp M, Martens K, Walraevens K (2011) Groundwater exploitation and recharge rate estimation of a quaternary sand aquifer in Dar-es-Salaam area, Tanzania. Environ Earth Sci 63:559-569

Mjemah IC, Mtoni Y, Elisante E, Tungaraza CT, Mtakwa PW, Walraevens K (2012) Sources of salinity in the Quaternary sand aquifer of Dar-es-Salaam, Tanzania. In: da Silva GC Jr, and Montenegro SMGL (eds). Proceedings of the 22nd Saltwater Intrusion Meeting (SWIM), Buzios, Brazil, 17-21 June, 2012, META: Buzios, Brazil, pp 264-267

Mtoni YE (2013) Saltwater intrusion in the coastal strip of Dar es Salaam Quaternary aquifer. University of Gent, Tanzania

Mtoni YE, Mjemah I, Msindai K, Van Camp M, Walraevens K (2012) Saltwater intrusion in the Quaternary aquifer of the Dar es Salaam Region, Tanzania. Geol Belg 15:16-25

Mtoni Y, Mjemah IC, Bakundukize C, Van Camp M, Martens K, Walraevens K (2013) Saltwater intrusion and nitrate pollution in the coastal aquifer of Dar es Salaam, Tanzania. Environ Earth Sci 70:1091-1111

Mueller DK (1995) Nutrients in ground water and surface water of the United States: An analysis of data through 1992. USGS WaterResources Investigations Report: 95-4031. US Geological Survey: Earth Science Information Center, Open-File Reports Section, $\mathrm{p} 74$

Napacho ZA, Manyele SV (2010) Quality assessment of drinking water in Temeke District (part II): characterization of chemical parameters. Afr J Environ Sci Technol 4:775-789

NBS and Office of Chief Stastitian Zanzibar (2013) 2012 Population and Housing Census: Population Distribution by Administrative Areas. United Republic of Tanzania, Dar es Salaam. http://ihi. eprints.org/1344/. Accessed 26 April 2014

Nicholson SE (1996) A review of climate dynamics and climate variability in Eastern Africa. In: Johnson TC, Odada EO (eds) The Limnology, climatology and paleoclimatology of East African Lakes. Gordon and Breach Publishers, Amsterdam, pp 25-56

Nishikawa T, Densmore JN, Martin P, Matti J (2003) Evaluation of the Source and Transport of High Nitrate Concentrations in Ground Water, Warren Subbasin, California. Water-Resources Investigations Report 03-4009. U.S. Geological Survey Sacramento, California, p 146

Nkotagu H (1996a) Origins of high nitrate in groundwater in Tanzania. J Afr Earth Sc 22:471-478

Nkotagu H (1996b) The groundwater geochemistry in a semi-arid, fractured crystalline basement area of Dodoma, Tanzania. J Afr Earth Sci 23:593-605

Nkotagu H (1996c) Application of environmental isotopes to groundwater recharge studies in a semi-arid fractured crystalline basement area of Dodoma, Tanzania. J Afr Earth Sci 22:443-457

Oenema O, van Liere L, Schoumans O (2005) Effects of lowering nitrogen and phosphorus surpluses in agriculture on the quality of groundwater and surface water in the Netherlands. J Hydrol 304:289-301

Orebiyi EO, Awomeso JA, Idowu OA, Martins O, Oguntoke O, Taiwo AM (2010) Assessment of pollution hazards of shallow well water in Abeokuta and environs, southwest, Nigeria. Am J Environ Sci 6:50-56

Panno SV, Kelly WR, Martinsek AT, Hackley KC (2006) Estimating background and threshold nitrate concentrations using probability graphs. Groundwater 44:697-709 
Pittalis D (2010) Interdisciplinary studies for the knowledge of the groundwater fluoride contamination in the eastern African rift: Meru district-North Tanzania, University of Sassari

Policy and Operations Evaluation Department (IOB) (2007), US. Water Supply and Sanitation Programmes Shinyanga Region, Tanzania 1990-2006. IOB Impact Evaluation no. 305. p 174. www.oecd.org/countries/tanzania/42401172.pdf. Accessed 12 May 2014

Rajesh R, Brindha K, Murugan R, Elango L (2012) Influence of hydrogeochemical processes on temporal changes in groundwater quality in a part of Nalgonda district, Andhra Pradesh, India. Environ Earth Sci 65:1203-1213

Reynolds-Vargas J, Fraile-Merino J, Hirata R (2006) Trends in nitrate concentrations and determination of its origin using stable isotopes $\left({ }^{18} \mathrm{O}\right.$ and $\left.{ }^{15} \mathrm{~N}\right)$ in groundwater of the western Central Valley, Costa Rica. Ambio J Hum Environ 35:229-236

Rwebugisa RA (2008) Groundwater re-charge assessment in the Makutupora Basin, Dodoma, Tanzania. International Institute for Geo-Information Science and Earth Observation, Enschede

Sheuya SA (2010) The Human Settlements Financing Tools and Best Practices Series: Informal Settlements and Finance in Dar es Salaam, Tanzania, UN-HABITAT, Nairobi Kenya, p 66

Spalding RF, Exner ME (1993) Occurrence of nitrate in groundwater. A review. J Environ Qual 22:392-402

Srinivasamoorthy K, Chidambaram S, Sarma VS, Vasanthavigar M, Vijayaraghavan K, Rajivgandhi R, Anandhan P, Manivannan R (2009) Hydrogeochemical characterisation of groundwater in Salem District of Tamilnadu, India. Res J Environ Earth Sci $1: 22-33$

Sumner GN (1983) Daily rainfall variability in coastal Tanzania, Geografiska Annaler. Ser A Phys Geogr 65:53-66

Taylor RG, Todd MC, Kongola L, Maurice L, Nahozya E, Sanga H, MacDonald AM (2012) Evidence of the dependence of groundwater resources on extreme rainfall in East Africa. Nat Clim Change 3:374-378
Tredoux G, Talma AS, Engelbrecht JFP (2000) The increasing nitrate hazard in groundwater in the rural areas. Presented at the WISA 2000 Biennial Conference, Sun City, South Africa, 28 May-1 June 2000, p 12

Tungaraza C, Eliapenda E, Osewe KO, Palapala PM (2012) Longterm climate impact on the Lake Victoria region influences water level fluctuation and resource availability. Int J Environ Sci 2:1717-1732

UN (2004) World Population to 2300. (New York: United Nations, Department of Economic and Social Affairs. www.unpopulation. org. Accessed 12 January 2014

United Republic of Tanzania (2008) Nine Water Basins. United Republic of Tanzania, Ministry of Water. http://www.maji.go.tz/ basins/nine.php. Accessed 1 February 2013

USFS (2009) Water Quality and Water Source Protection in Kigoma and Tabora Regions, Tanzania. US Forest Service Technical Assistance Mission. November 8-23, 2009

Wakida FT, Lerner DN (2005) Non-agricultural sources of groundwater nitrate: a review and case study. Water Res 39:3-16

Wendland F, Hannappel S, Kunkel R, Schenk R, Voigt HJ, Wolter R (2005) A procedure to define natural groundwater conditions of groundwater bodies in Germany. Water Sci Technol 51:249-257

West D (2001) Nitrates in Ground Water A Continuing Issue for Idaho Citizens. Groundwater Quality Information Series No. 1.Idaho Department of Environmental Quality

WHO (2007) Nitrate and nitrite in drinking water. Background document for development of World Health Organization Guidelines for drinking-water quality. WHO/SDE/WSH/07.01/ 16 , Geneva, Switzerland

Yanda PZ, Munishi PKT (2007) Hydrologic and land use/cover change analysis for the Ruvu River (Uluguru) and Sigi River (East Usambara) watersheds. For WWF/CARE Dar es Salaam, Tanzania 